\title{
TITLE:
}

\section{LIFE CYCLE AND SYSTEMATIC POSITION OF POLYPODIUM HYDRIFORME USSOV (COELENTERATA), A CNIDARIAN PARASITE OF THE EGGS OF ACIPENSERIDAE}

\author{
$\operatorname{AUTHOR}(\mathrm{S}):$ \\ Raikova, E. V.
}

\section{CITATION:}

Raikova, E. V.. LIFE CYCLE AND SYSTEMATIC POSITION OF POLYPODIUM HYDRIFORME USSOV (COELENTERATA), A CNIDARIAN PARASITE OF THE EGGS OF ACIPENSERIDAE. PUBLICATIONS OF THE SETO MARINE BIOLOGICAL LABORATORY 1973, 20: 165-173

\section{ISSUE DATE:}

1973-12-19

URL:

http://hdl.handle.net/2433/175780

RIGHT: 


\title{
LIFE CYCLE AND SYSTEMATIC POSITION OF POLYPODIUM HYDRIFORME USSOV (COELENTERATA), A CNIDARIAN PARASITE OF THE EGGS OF ACIPENSERIDAE
}

\author{
E.V. RAIKOVA \\ Institute of Cytology, Academy of Sciences of the USSR, Leningrad
}

With Plates I-III and 1 Text-figure

Polypodium hydriforme is the only representative of the coelenterates adapted to intracellular parasitism-to dwelling within the oocytes of the Acipenseridae. This organism was discovered at the end of the last century by F.V. OvsJannikov, and thoroughly studied later by A.N. LIPIN. However, many questions of its biology remained unsolved. Polypodium has been found until now in the oocytes of Acipenser ruthenus (sterlet), A. güldenstädti (sturgeon), A. stellatus, A. nudiventris and A. schrenki in the Volga, the Don, the Dnieper, the Dniester, the Kuban, the Danube, the Sulak, the Syr-Daria and the Amur. Our studies performed at the Volga and the Kama showed the sterlet to be the most infected species (about $80 \%$ of the mature females), the sturgeon being less affected (20\% of the mature females). In other hosts Polypodium was found only sporadically.

It is in the sterlet ( $A$.ruthenus) that Polypodium was studied in most detail. Each maturation stage of the fish ovaria proved to correspond to a definite stage of the development of the parasite, i.e. the life cycle of the latter is closely correlated with the maturation cycle of the host gonads (Text-figure 1).

The earliest of the investigated stages of the Polypodium life cycle was found in the ovaria of a post-spawning sterlet in July. In young oocytes, about $100 \mu$ in diameter (P1. I, Fig. 1), before the beginning of the vitellogenesis, the parasite is represented by one cell, $20-30 \mu$ in diameter, with two nuclei of unequal sizes: a small one and a large one (Pl. I, Fig. 2). Photometrical studies showed the small nucleus to be haploid, while the large one proved to be polyploid to $400 \mathrm{n}$. While the oocyte grows, the large nucleus of the parasite forms a deep cavity and the small nucleus (with some cytoplasm differentiating around it) enters therein (P1. I, Fig. 3). The cell thus formed around the small nucleus becomes completely surrounded by the large nucleus and later gives rise to the cleaving blastomeres of the embryo (Pl. I, Figs. 4, 5). The main mass of the cytoplasm of the binuclear cell and the large nucleus form together a peculiar capsule surrounding the parasite and carrying out feeding functions. The polyploid nucleus of the capsule splits later into polymorphic nuclei, closely adjacent to one another and lying in the common cytoplasm of the capsule (Pl. I, II; Fig. 5,6). The 


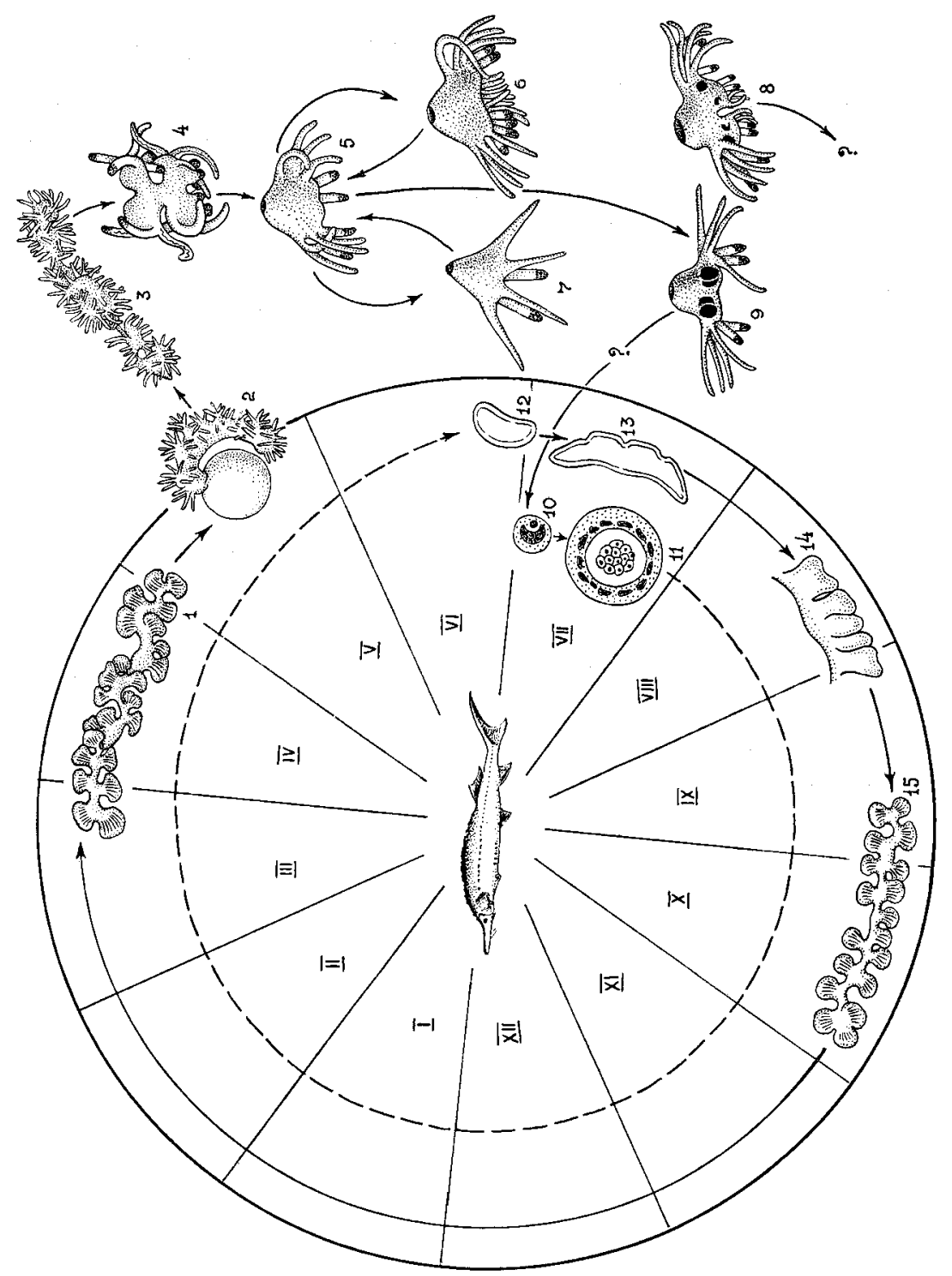

Text-fig. 1. Diagram of the life-cycle of Polypodium hydriforme.

Inside the circle are parasitic stages of the life-cycle, outside the circle are free-living stages.

I-XII are months of the year.

1 -stolon with inverted germ-layers (internal tentacles); 2 -at spawning of the host, stolon leaving the infected egg and now with external tentacles, i.e. with normal disposition of germ-layers; 3-stolon in water; 4-fragment of a stolon; 5-12-tentacled polyp; 6-24-tentacled polyp (vegetative reproduction); 7-6-tentacled polyp; 8-24 tentacled polyp with 4 "female" sexual complexes; 9-12-tentacled polyp with 4 "male" gonads;? means that the mode of infection is unknown; 10-binuclear parasitic cell inside a young oocyte; 11-morula encircled by a capsule; 12-planula (capsule not shown); 13-budding planula; 14-stolon still without tentacles; 15-stolon with internal tentacles. 
cleavage leads to the formation of a compact morula (PI. II, Fig. 6).

By the beginning of vitellogenesis an infected oocyte has contained already a twolayered planula-like larva, about $1 \mathrm{~mm}$ long (Pl. II, Fig. 7), which has an inverse disposition of the embryonic layers: the flagellated entoderm outside and the ectoderm inside. The larva is still surrounded by the capsule (Pl. II, Fig. 8). While the parasite grows, the capsule extends, but its substance is filled up at the cost of cells emigrating from the entoderm of the larva and joining the capsule. It is in the capsule that yolk digestion and glycogen accumulation take place.

In August, the planula-like larva grows into a stolon producing the first buds (Text-fig. 1, 14). At first the buds have no tentacles; the latter are formed in September (Text-fig. 1, 15), and then the stolon with internal tentacles hibernates within the oocyte. During autumn and winter, the capsule gradually degenerates, and yolk digestion is then carried out immediately by entodermic cells (Pl. II, Fig. 9). At this time the infected eggs are easily distinguished with a naked eye among the normal eggs (Pl. II, Fig. 10). In spring, before spawning, the stolon turns inside out within the fish egg so that the embryonic layers assume a normal disposition (ectoderm and tentacles outside). This process may be produced artificially by means of a hypophysis injection of the host fishes. During the spawning, the stolons of Polypodium get into water together with healthy eggs, and the free-living phase of its life cycle begins (Textfig. 1, 2-9).

In water, the stolon of Polypodium (having already a normal disposition of embryonic layers) (Pl. III, Fig. 11) is broken into fragments until solitary polyps, with 12 or 24 tentacles, are formed from respective buds (PI. III, Fig. 12). These polyps reproduce by longitudinal fission, the number of tentacles being doubled before each division. After formation of the mouth, the polyps feed actively, swallowing turbellarians and oligochaetes.

In July, two types of gonads are formed in polyps - at first the "female" ones, then the "male" ones. Along with one-sexed individuals, hermaphroditic animals are also met. The "female" sexual complex has a very complicated structure: it is an entirely entodermal formation, including two sexual glands, each with a gonoduct which opens into the gastral cavity (Pl. III, Fig. 13). The walls of the sexual glands produce diploid primary sexual cells, which come out through the gonoducts into the gastral cavity. Their further fate remains unknown. A polyp can have from 1 to 8 "female" sexual complexes.

The "male" gonads (4 in each specimen) have no gonoducts. These are paired entodermal protrusions into the gastral cavity (Pl. III, Fig. 14). After meiosis, they become filled with cells each having two nuclei of unequal sizes (Pl. III, Fig. 15). It has been shown photometrically that the small nucleus is haploid, while the large one immediately begins polyploidization, reaching $4 \mathrm{n}$ at this stage. The cavity of a mature gonad becomes "stoppered" with a special ectodermal disc containing cnidocytes (Pl. III, Fig. 14). Such gonads fall out of the body of the polyp as whole 
units. Cases are even known, where polyps actively attached these gonads to the bodies of very young larvae of Acipenser stellatus in the Volga (Pl. III, Fig. 16). The further fate of those cells of the "male" gonads, as well as the phenomena of fecundation, are not yet known, but it is very probable that the binuclear cells in the young oocytes of the sterlet are the same with those cells of the "male" gonads, but at a more advanced stage of polyploidization of the large nucleus.

In summary, the life cycle of Polypodium involves the alternation of two generations (parasitic and free-living ones) (Text-fig. 1), both capable of asexual reproduction. In addition the free-living generation is capable of sexual reproduction as well. Freeliving and parasitic generations belong, presumably, to medusoid and polypoid generations, respectively. The life cycle of Polypodium is thus a case of metagenesis. Some patterns of Polypodium organization are worthy to be stressed specially as they seem to be adaptations to a parasitic mode of life, such as: the presence of the capsule isolating the parasite from the oocyte cytoplasm and serving to its feeding; the inverse disposition of the embryonic layers; the complete absence of the sensory organs; the complicated structure of the reproductive system in comparison with other coelenterates. According to the general plan of body organisation, the type of nematocysts, the character of metagenesis, and the parasitism, Polypodium stands close to the order Narcomedusae. However, no form of Narcomedusae has been so far reported from fresh water. Moreover, the classification of Polypodium as a Narcomedusan or more broadly as a Hydrozoan is in contradiction to the entodermal origin of its gonads. It is supposed that Polypodium hydriforme may deserve to be separated in a special class within the Coelenterata.

\section{EXPLANATION OF PLATES I-III}

\section{PLATE I}

Fig. 1. Sterlet oocyte showing its nucleus $(\mathrm{N})$ and infection of unicellular stage of Polypodium hydriforme $(\mathrm{PC})$, section, $\times 600$.

Fig. 2. Binuclear cell (PC) showing large nucleus $(\mathrm{LN})$ and small nucleus $(\mathrm{SN})$ in the oocyte of sterlet, section, $\times 1800$.

Fig. 3. Small cell (SC) differentiating inside the large one which is forming the capsule (C) and retains a large hollow nucleus (LN), section, $\times 1800$.

Fig. 4. Small cell (SC) completely surrounded by large nucleus (LN) which becomes to be the nucleus of the capsule $(C)$, section, $\times 1800$.

Fig. 5. Three blastomeres (B) enclosed within the capsule (C) containing a large hollow polyploid nucleus $(\mathrm{NC})$, section through a sterlet oocyte, $\times 1350$.

\section{PLATE II}

Fig. 6. Cleaving morula (M) enclosed within the capsule (C) containing many nuclei formed by fragmentation of large hollow nucleus, section, $\times 280$. N-oocyte nucleus.

Fig. 7. Bilayered planula inside a sterlet oocyte, lying near the oocyte nucleus $(\mathrm{N})$, section, $\times 50$.

Fig. 8. Capsule (C) with several nuclei (NC) separating the planula from the oocyte cytoplasm. Ectoderm (ECT) of planula is internal, entoderm (ENT) external (inversion of germ layers), section, $\times 900$. 
Fig. 9. Section through a fully grown sterlet oocyte infected with a stolon (ST) having internal tentacles (inversion of the germ layers). The host oocyte still contains some yolk (Y) and nucleus $(\mathrm{N}), \times 25$.

Fig. 10. Sterlet ovary showing mature eggs of which four (the larger ones) are infected with Polypodium hydriforme. They contain stolons with internal tentacles, in vivo, about $\times 2$.

\section{PLATE III}

Fig. 11. Stolon of Polypodium hydriforme in water. In vivo, about $\times 5$.

Fig. 12. Free living solitary polyp with 24 tentacles (T), just dividing, showing mouth by arrow, in vivo, about $\times 10$.

Fig. 13. Section of a "female" sexual complex, section, $\times 400$. ECT-ectoderm, ENT-entoderm, O-oviduct.

Fig. 14. Section of a "male" gonad filled with binuclear cells $(B C)$ and supplied with an ectodermal plate (ECT) containing cnidocysts (shown by arrow), section, $\times 200$. ENT-entoderm.

Fig. 15. Binuclear cells, each with a large nucleus and a small one, in the "male" gonad, section, $\times 1800$.

Fig. 16. Free-living polyp depositing its "male" gonad (G) on the tail of a larva of Acipenser stellatus, about $\times 10$. 
Proc. Second Internat. Symp. Cnidaria
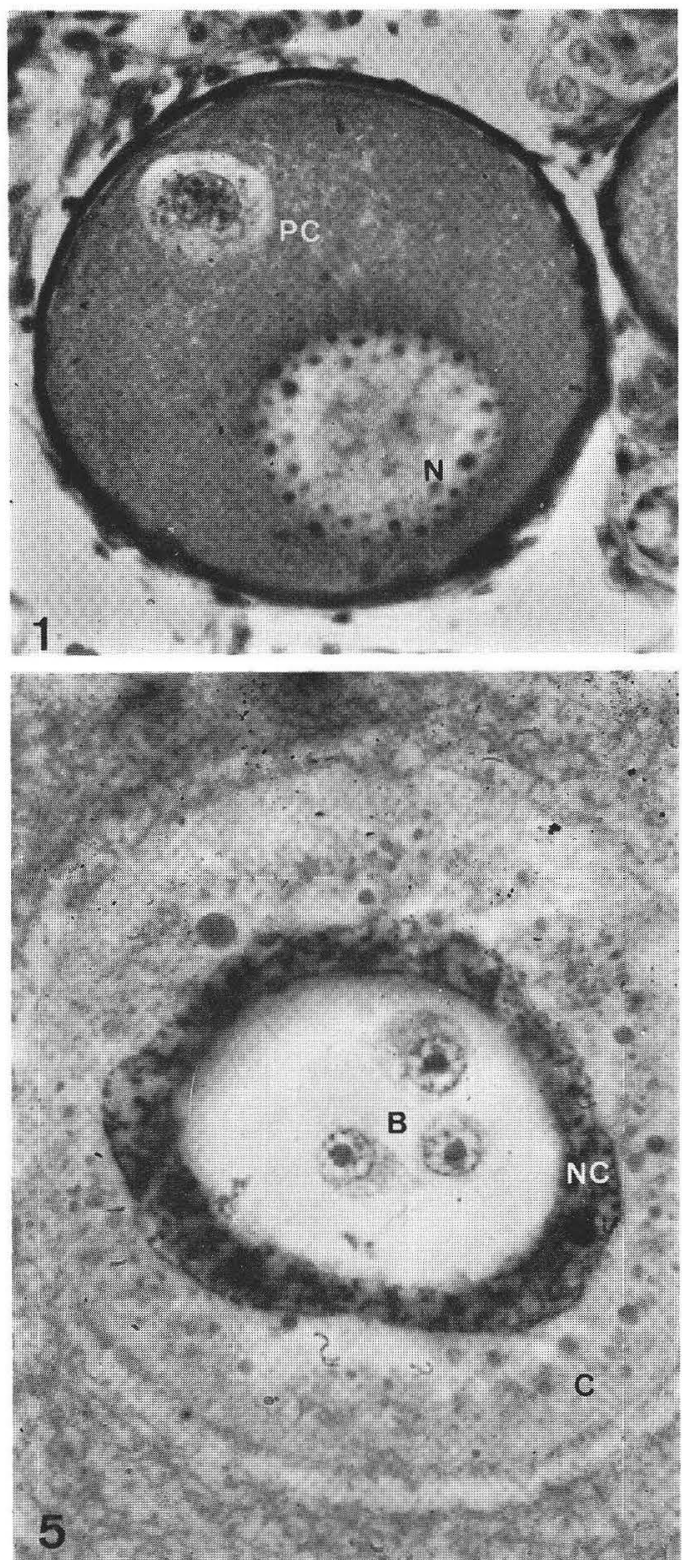

PLATE I
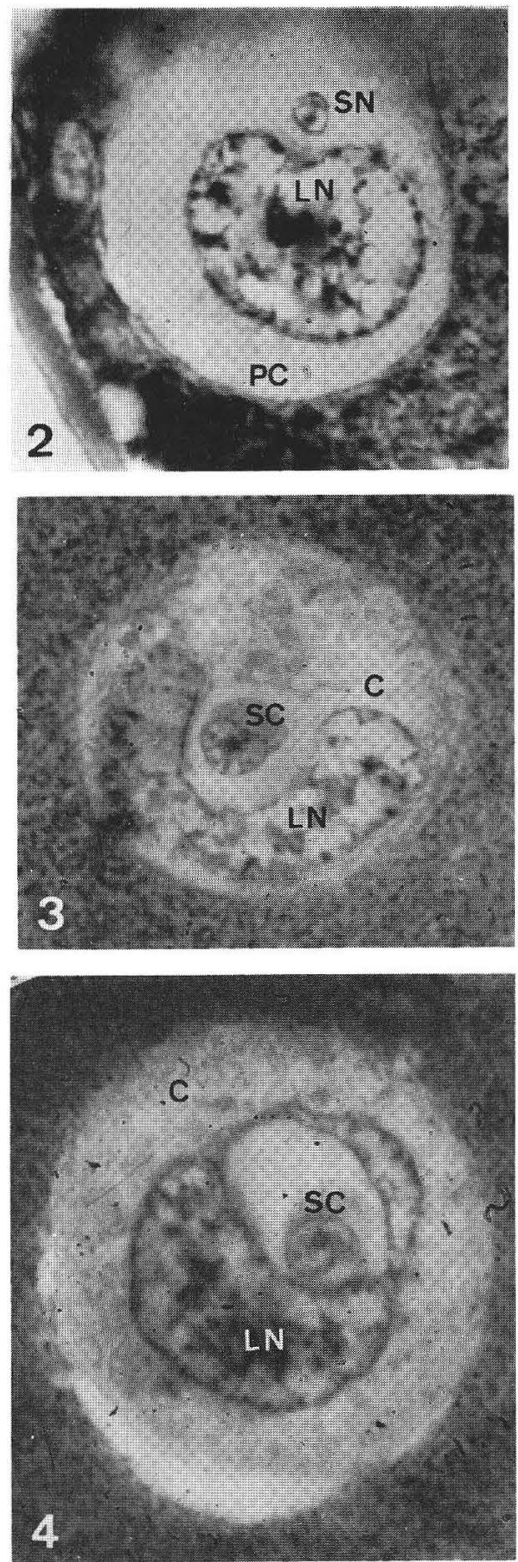

E. V. Raikova : Life Cycle and Systematic Position of Polypodium 

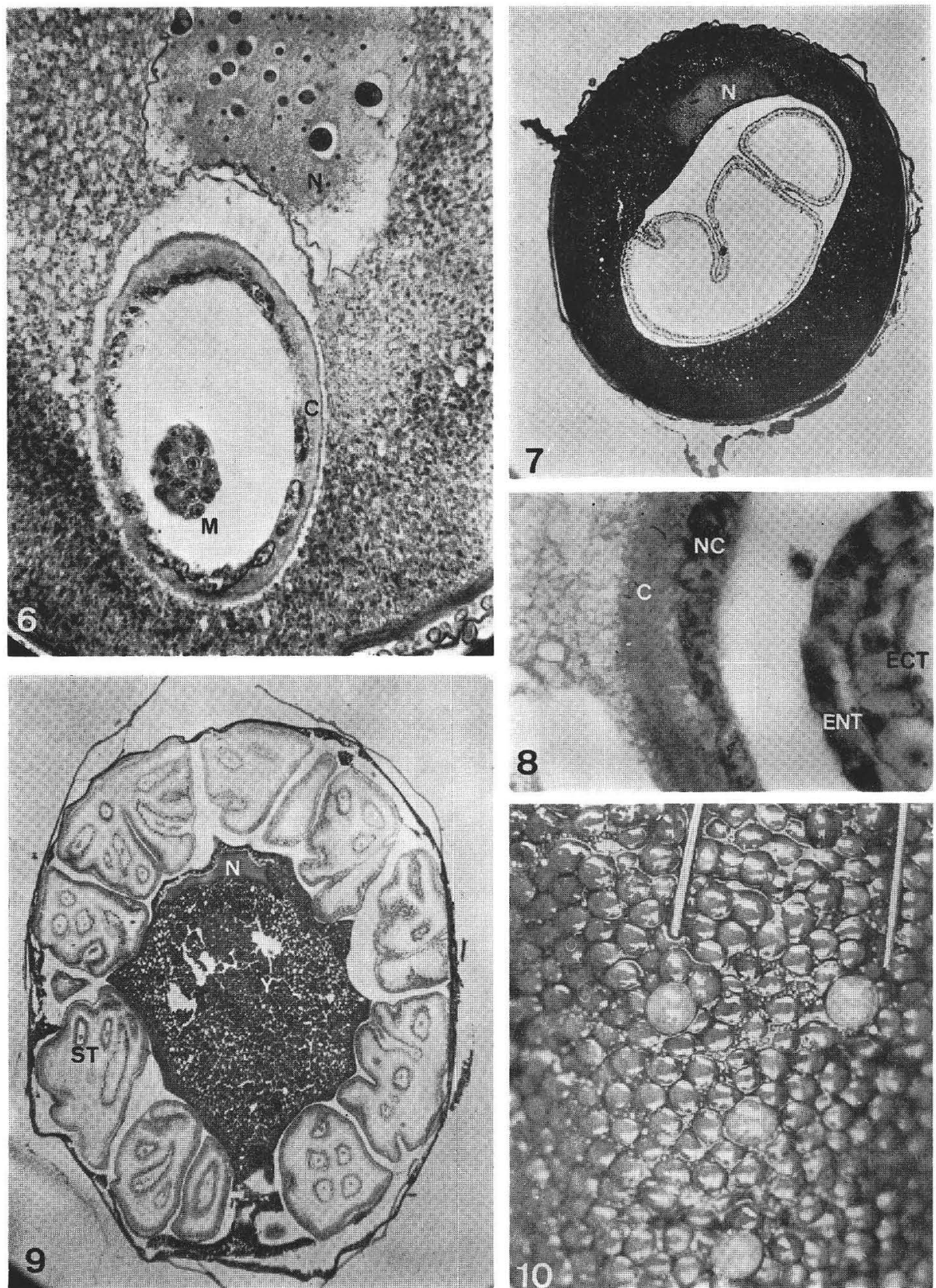

E. V. Raikova : Life Cycle and Systematic Position of Polypodium 
Proc. Second Internat. Symp. Cnidaria

PLATE III
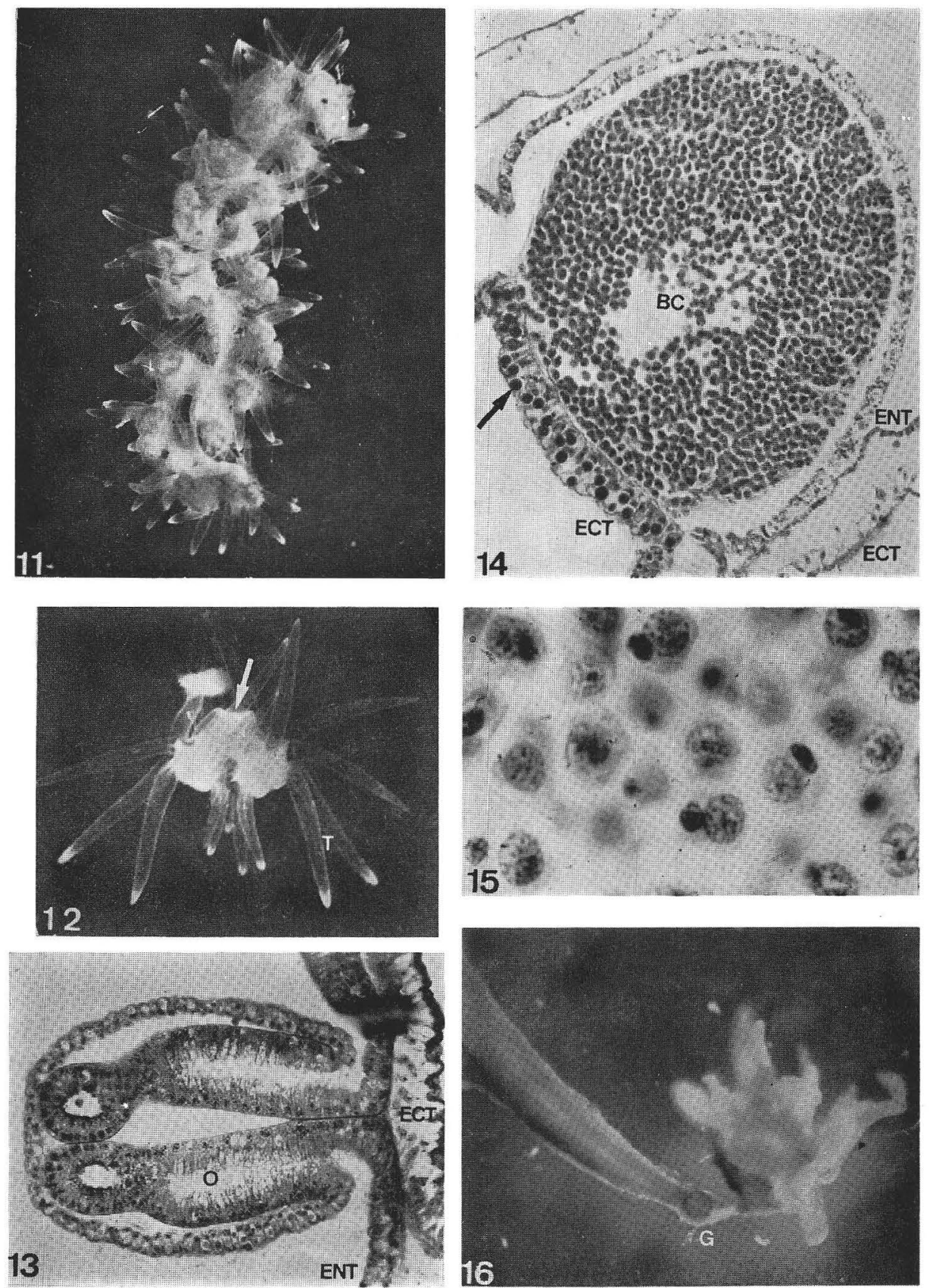

E. V. RaIkova : Life Cycle and Systematic Position of Polypodium 